This work is licensed under a Creative Commons Attribution 3.0 License.

\title{
A new genus of ground and litter-dwelling pholcine spiders from Sarawak (Araneae, Pholcidae)
}

\author{
Bernhard A. HUBER \\ Alexander Koenig Research Museum of Zoology, Adenauerallee 160, 53113 Bonn, Germany. \\ Email: b.huber@zfmk.de \\ urn:1sid:zoobank.org:author:33607F65-19BF-4DC9-94FD-4BB88CED455F
}

\begin{abstract}
Two small, ground and litter-dwelling pholcid species from northern Borneo are described as representatives of a new genus, Hantu gen. nov.: H. kapit gen. et sp. nov. and H. niah gen. et sp. nov. Previous cladistic analyses suggested a closer relationship with the genera Savarna Huber, 2005 and Khorata Huber, 2005 (mainland Southeast Asia) than with the geographically closer genus Aetana Huber, 2005 (Borneo and Philippines to Fiji). Since the two species do not share any of the synapomorphies of Khorata and Savarna while having several synapomorphies on their own (ventral apophysis on male palpal coxa; male palpal trochanter apophysis with small teeth or scales; spines on male femora 1; high density of vertical hairs on male femora; presence of scape on epigynum), they are here proposed as representing a new genus.
\end{abstract}

Keywords. Borneo, Sarawak, endemism, taxonomy, Pholcidae.

Huber B.A. 2016. A new genus of ground and litter-dwelling pholcine spiders from Sarawak (Araneae, Pholcidae). European Journal of Taxonomy 186: 1-15. http://dx.doi.org/10.5852/ejt.2016.186

\section{Introduction}

The two species newly described herein were initially to be included in a revision of the Southeast Asian pholcid genus Aetana Huber, 2005 (Huber et al. 2015a). Superficially, they resembled ground and litter-dwelling representatives of that genus, and their geographic origin also pointed towards Aetana (ranging from Borneo and the Philippines to Fiji) rather than to other similar genera on the Southeast Asian mainland (Savarna Huber, 2005; Khorata Huber, 2005). However, closer examination and cladistic analyses revealed that these two species (under the names "Gen.n. Bor80" and "Gen.n. Bor20" in Huber et al. 2015a) were not only different from Aetana in many details, but, in fact, closer to Khorata and Savarna. At the same time, the two species do not share any of the distinctive characters of Khorata (Huber 2005b) and Savarna (Huber 2005b; Huber et al. 2015b). As a consequence, they are here described as representatives of a new genus.

\section{Material and methods}

The material studied herein was collected during a recent expedition to northern Borneo (Jul.-Aug. 2014). It is currently deposited at the Zoologisches Forschungsmuseum Alexander Koenig, Bonn (ZFMK), and the Sarawak Museum, Kuching (SMK). 
Methods and terminology are as in recent revisions (Huber 2011, 2013). Measurements are in mm unless otherwise noted. Eye measurements are $\pm 5 \mu \mathrm{m}$. Epigyna were cleared in warm $\mathrm{NaOH}$ solution and stained with chlorazol black. For SEM photos, specimens were dried in HMDS (Brown 1993), and photographed with a Hitachi S-2460 scanning electron microscope. SEM data are presented within the descriptions, but are not based on the holotype specimens described. The distribution map was generated with ArcMap 10.0. The following abbreviations are used in the text:

ALE $=$ anterior lateral eyes

ALS $=$ anterior lateral spinnerets

$\mathrm{AME}=$ anterior median eyes

a.s.l. = above sea level

$\mathrm{L} / \mathrm{d}=$ length/diameter

$\mathrm{PME}=$ posterior median eyes

Further abbreviations used only in figures are explained directly in the figure legends.

\section{Results}

Class Arachnida Cuvier, 1812

Order Araneae Clerck, 1757

Family Pholcidae C.L. Koch, 1851

Hantu gen. nov.

urn:1sid:zoobank.org:act:9DBCF7B6-8A03-4346-BFA7-9DE99CD065D7

\section{Type species}

Hantu kapit gen. et sp. nov.

\section{Diagnosis}

Small, six-eyed, dark, ground and litter-dwelling pholcids with dark (usually black) sternum, with thoracic furrow extending over entire length of carapace, and without epiandrous spigots. Distinguished from putatively closest known relatives (Khorata, Savarna) by ventral apophysis on male palpal coxa (arrows in Figs 9, 19, 27), by scales or teeth on male palpal trochanter (Fig. 16), by spines on male femora 1 ( 10-25 in single ventral row), by short vertical hairs in high density on male femora (in two dorsal rows), and by scape on female external genitalia (Figs 40-45); from Savarna also by presence of distal cheliceral apophyses (Figs 11,28) and by male palpal trochanter apophysis not fused to femur (Figs 9, 27); from Khorata also by absence of sclerotized ledges laterally on male chelicerae (Figs 11, 28 ) and by absence of retrolateral process on male palpal femur (Figs 9, 27).

\section{Etymology}

Named for the Hantu Rimba, deep-forest ghosts in traditional Malaysian mythology. Gender masculine.

\section{Description}

\section{Male}

Measurements. Total body length $\sim 2.0-2.5$; carapace width $0.9-1.0$; leg 1 length $\sim 20-25$; tibia 1 length $\sim 4.5-6.0$; tibia 2/tibia 4 length 1.0-1.1; tibia $1 \mathrm{~L} / \mathrm{d} \sim 55-75$.

CoLoR. In life (Figs 1-6) mostly ochre-gray with black marks, sternum black, legs without dark rings; abdomen with dark brown to black marks dorsally, laterally, and ventrally.

BoDy. Carapace with distinct median furrow (Figs 14, 31, 34); ocular area raised, eye triads on short stalks directed toward lateral (Figs 14, 31), with complex modification in H. kapit gen. et sp. nov. (Figs 10, 
HUBER B.A., New spider genus from Sarawak

14, 15, 17). AME absent. Clypeus high, either unmodified or with small median process (Figs 15, 17). Abdomen slightly longer than high, pointed at spinnerets (Figs 1-6). Male gonopore without epiandrous spigots (Figs 23, 32). ALS with large widened spigot and pointed spigot, without further cylindrically shaped spigots (Figs 24, 38); PMS with two spigots each.

Chelicerae. With two pairs of processes, one proximal lateral, one distal frontal (Figs 11, 28); without modified hairs; without stridulatory ridges.

PALPS. Coxa with distinct ventral process (Figs 8, 19, 27); trochanter with retrolateral process of varying length provided with small scales or teeth (Fig. 16); femur large, without processes; patella relatively long ventrally (not triangular in lateral view; Figs 9, 27); tibia rather small and slender, with retrolateral trichobothrium in 'normal' (not very distal) position (at $\sim 60 \%$ of tibia length); palpal tarsus small, with pit-shaped rather than capsular tarsal organ (Figs 21, 33); procursus complex, proximal and distal parts connected by membranous hinge; bulb with weakly sclerotized embolus as only process (Figs 9, 27).

LEGS. With spines on femora 1; without curved hairs; vertical hairs in two dorsal rows on all femora and tibiae; retrolateral trichobothrium on tibia 1 at $\sim 6-8 \%$ of tibia length; prolateral trichobothrium absent on tibia 1, present on other tibiae. Tarsal organ not examined. Tarsus 1 with $\sim 15-20$ pseudosegments fairly distinct distally; tarsus 4 with single row of ventral comb-hairs of Belisana-type (cf. Huber \& Fleckenstein 2008) (Figs 25, 39).

\section{Female}

Similar to male but eye triads on low humps (Fig. 34); clypeus and chelicerae unmodified; legs slightly shorter than in male (tibia $1 \sim 4.0-5.0$ ); without spines on femora 1 . Epigynum weakly sclerotized, with distinct scape directed toward posterior (Figs 12, 29, 40-45). Internal genitalia with pair of oval pore plates.

\section{Monophyly and relationships}

In a recent morphological cladistic analysis of Aetana and putatively close relatives (Huber et al. 2015a), the monophyly of Hantu gen. nov. was consistently supported by five synapomorphies: (1) presence of ventral apophysis on male palpal coxa (Figs 9, 19,27); (2) male palpal trochanter apophysis with small teeth or scales (Fig. 16); (3) presence of spines on male femora 1; (4) high density of vertical hairs on male femora; (5) presence of scape on epigynum (Figs 40-45).

Three characters suggested a closer relationship with the mainland genera Khorata and Savarna rather than with Aetana: (1) thoracic furrow extending over entire length of carapace (Figs 14, 31, 32); (2) dark (usually black) sternum; and (3) absence of epiandrous spigots (Figs 23, 32). A single character supported a sister-group relationship with Savarna: high density of vertical hairs on tibiae. Preliminary molecular data (A. Valdez-Mondragón, D. Dimitrov, B.A. Huber, unpubl. data) are not conclusive: while H. niah gen. et sp. nov. is placed in a clade together with Khorata and Savarna (in agreement with morphology), H. kapit gen. et sp. nov. is currently misplaced in Belisana Thorell, 1898 for unknown reasons.

\section{Natural history}

Both species were found in small protected spaces close to the ground (in small holes; among and under rocks, logs, and large leaves) where they build their domed webs.

\section{Composition}

Only the two species newly described below.

\section{Distribution}

Known from Sarawak only (Fig. 7). 


\section{Hantu kapit gen. et sp. nov.}

urn:lsid:zoobank.org:act:C86E7783-5E91-4FB9-AB7E-A7F32FDA9431

Figs $1-2,8-25,40-42$

Gen.n. Bor80 - Huber et al. 2015a: 73-74.

\section{Diagnosis}

Easily distinguished from $H$. niah gen. et sp. nov. (and from other putatively close relatives in the genera Khorata, Savarna, and Aetana) by two pairs of horns on male ocular area (Figs 10, 14, 15, 17),
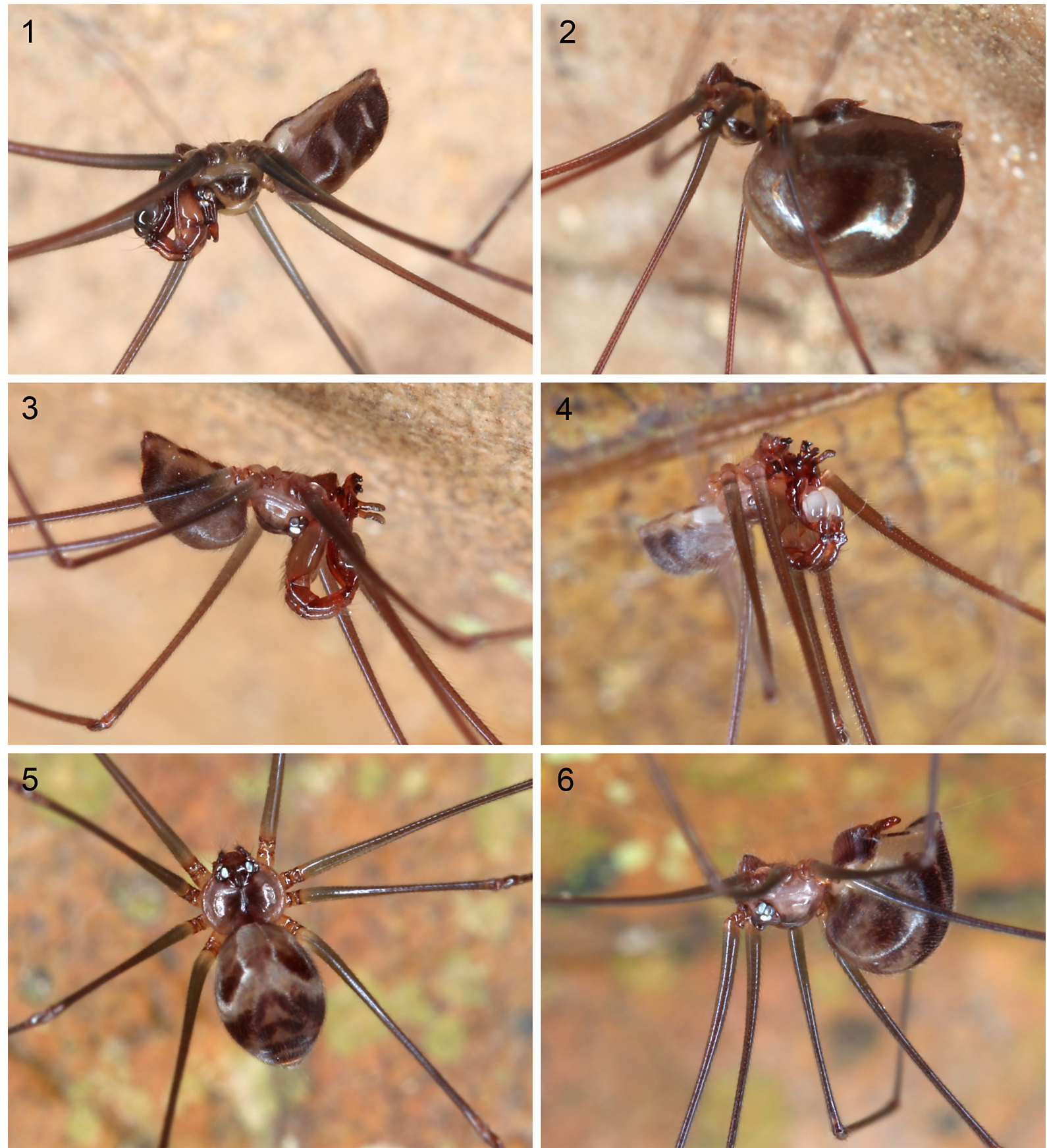

Figs 1-6. Live specimens. 1-2. Hantu kapit gen. et sp. nov., $O^{1}$ and $\odot$ from Kapit, Sarawak. 3-6. Hantu niah gen. et sp. nov., $\hat{\sigma}$ and $\phi$ from Niah, Sarawak. 
HUBER B.A., New spider genus from Sarawak

by extremely long apophysis on male palpal trochanter (longer than femur; Fig. 9), and by scape on epigynum (Fig. 40) less sclerotized than in H. niah gen. et sp. nov. and with fine transversal folds.

\section{Etymology}

The species name is derived from the type locality; noun in apposition.

\section{Type material}

MALAYSIA-BORNEO: holotype, ${ }^{\wedge}$, Sarawak, near Kapit, forest along river, 1.937-1.944 N, 112.904 $112.910^{\circ}$ E, 80-120 m a.s.l., 20 Jul. 2014 (B.A. Huber, S.B. Huber), ZFMK (Ar 15068).

\section{Other material examined}

MALAYSIA-BORNEO, Sarawak: $7 \hat{\jmath} \hat{\partial}, 4$ 우, same data as holotype, ZFMK (Ar 15069-70; $6 \hat{\jmath} \widehat{\partial}$, 3 우) and SMK (1 0 , 1 ㅇ); 2 우, 4 juvs, same data, in pure ethanol, ZFMK (Bor 183).

\section{Description}

Male (holotype)

Measurements. Total body length 2.4, carapace width 0.9. Leg 1: $24.5(5.8+0.4+5.7+9.3+3.3)$, tibia 2: 3.4, tibia 3: 2.4, tibia 4: 3.1; tibia 1 L/d: 72. Distance PME-PME $500 \mu \mathrm{m}$, diameter PME $105 \mu \mathrm{m}$, distance PME-ALE $25 \mu \mathrm{m}$, no AME.

CoLOR. Carapace pale ochre with large dark lateral marks and median mark posteriorly, dark median line, ocular area and clypeus dark brown. Sternum dark brown to black. Legs ochre to light brown, without dark rings. Abdomen ochre-grey with large dorsal and lateral marks; ventral side largely covered by large dark mark and smaller dark mark at spinnerets.

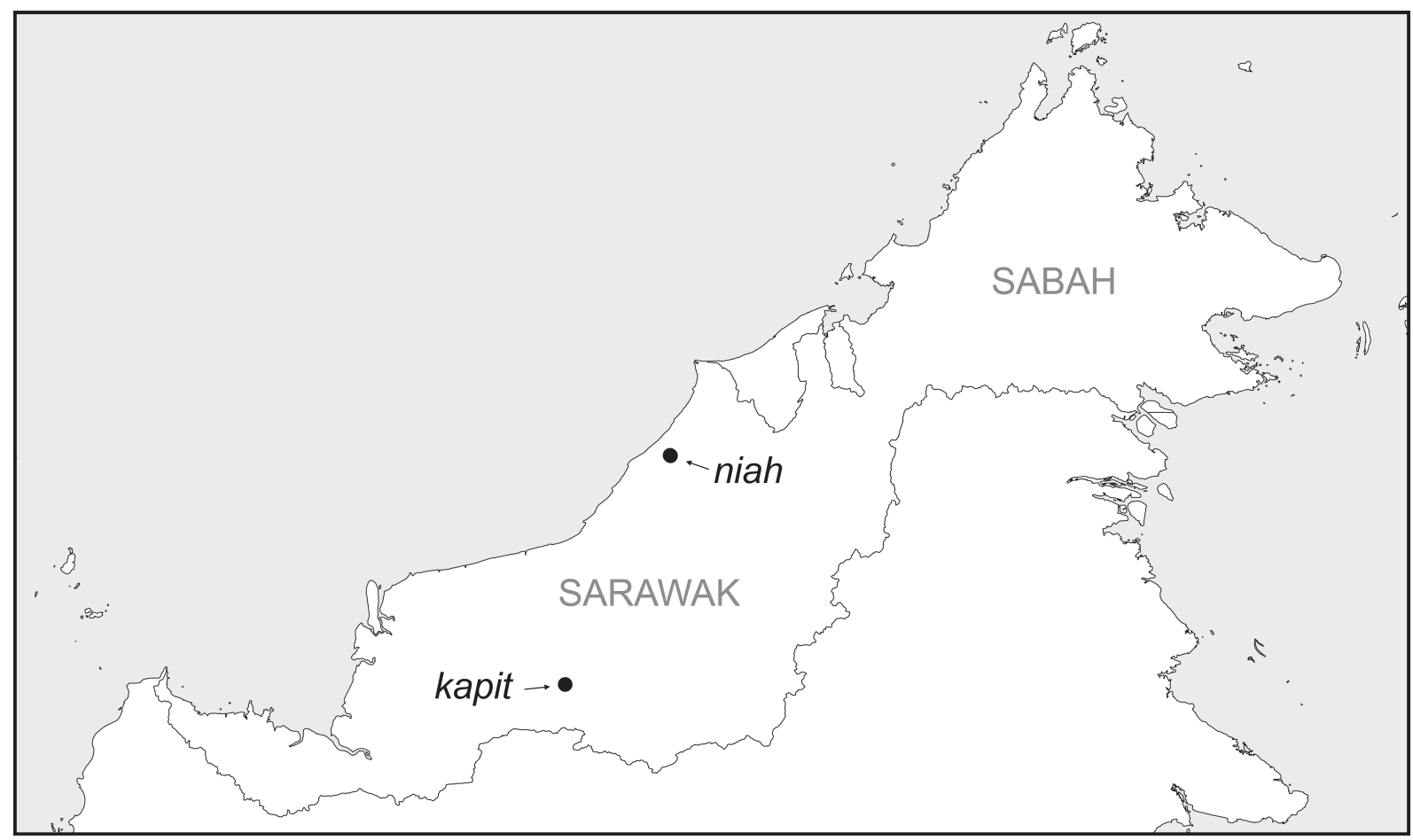

Fig. 7. Map of northern Borneo, showing known records of Hantu gen. nov. 
Body. Habitus as in Fig. 1; ocular area highly modified (Figs 10, 14, 15, 17), with two pairs of large horns arising from near PME and PLE and pair of smaller processes arising from near ALE; each triad on short stalk directed toward lateral; carapace with distinct thoracic furrow; clypeus with small median

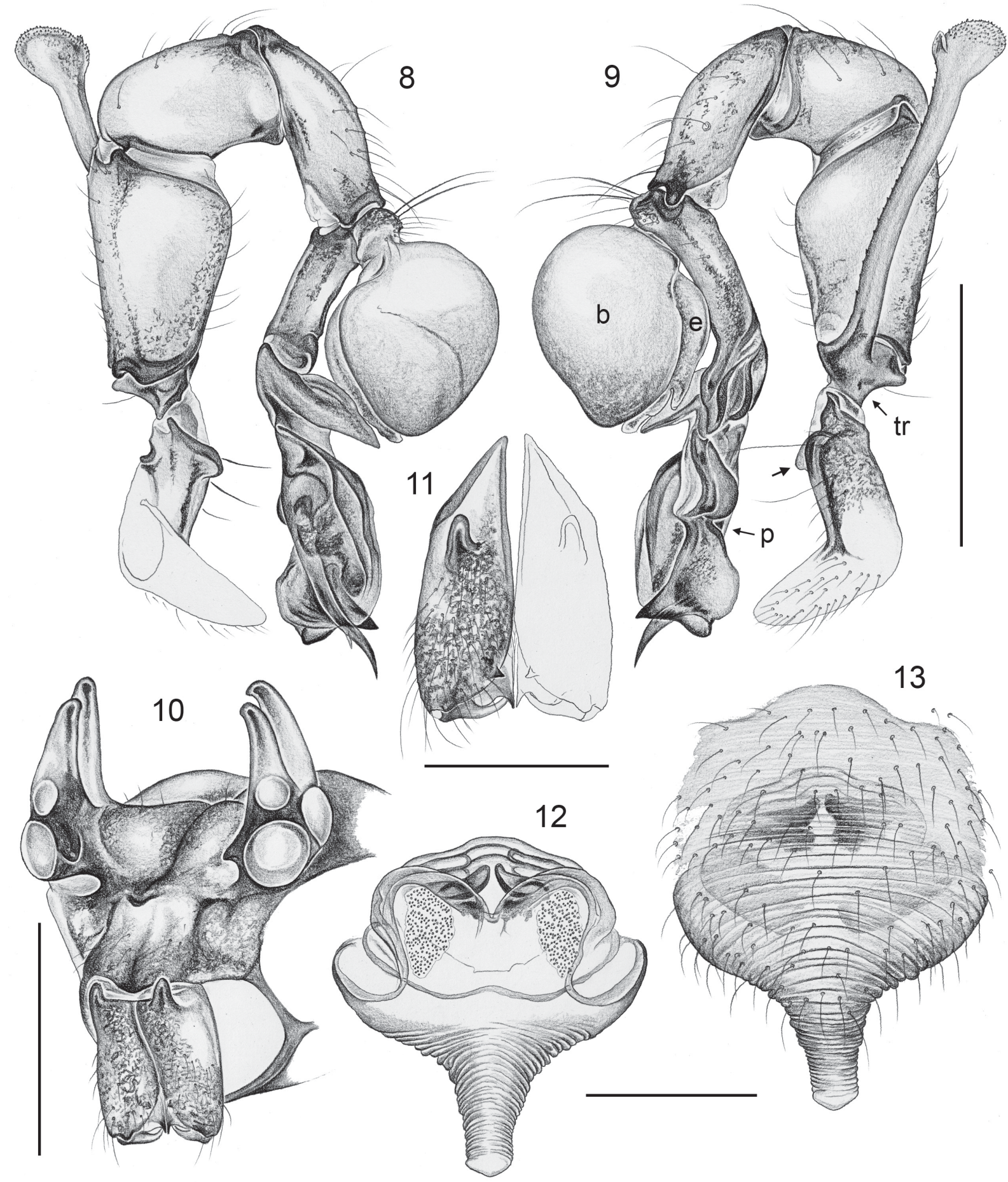

Figs 8-13. Hantu kapit gen. et sp. nov., ZFMK Ar 15069-70. 8-9. Left male palp, prolateral and retrolateral views (arrow points at ventral process on coxa). 10. Male prosoma, oblique frontal view. 11. Male chelicerae, frontal view. 12-13. Cleared female genitalia, dorsal and ventral views. Abbreviations: $b=$ genital bulb; $\mathrm{e}=$ embolus; $\mathrm{p}=$ procursus; $\mathrm{tr}=$ trochanter. Scale lines: $0.5 \mathrm{~mm}(8-10) ; 0.3 \mathrm{~mm}(11-13)$. 
HUBER B.A., New spider genus from Sarawak

process (Figs 15, 17); sternum wider than long (0.60/0.50), unmodified. Chelicerae as in Fig. 11, with pair of proximal lateral apophyses in rather frontal position and pair of small, distal apophyses near lamellae; without modified hairs.

PALPS. As in Figs 8-9, coxa with sclerotized protruding rim ventro-distally; trochanter with distinctive long retrolateral apophysis widening distally and provided with small teeth at tip (Fig. 16); femur large,
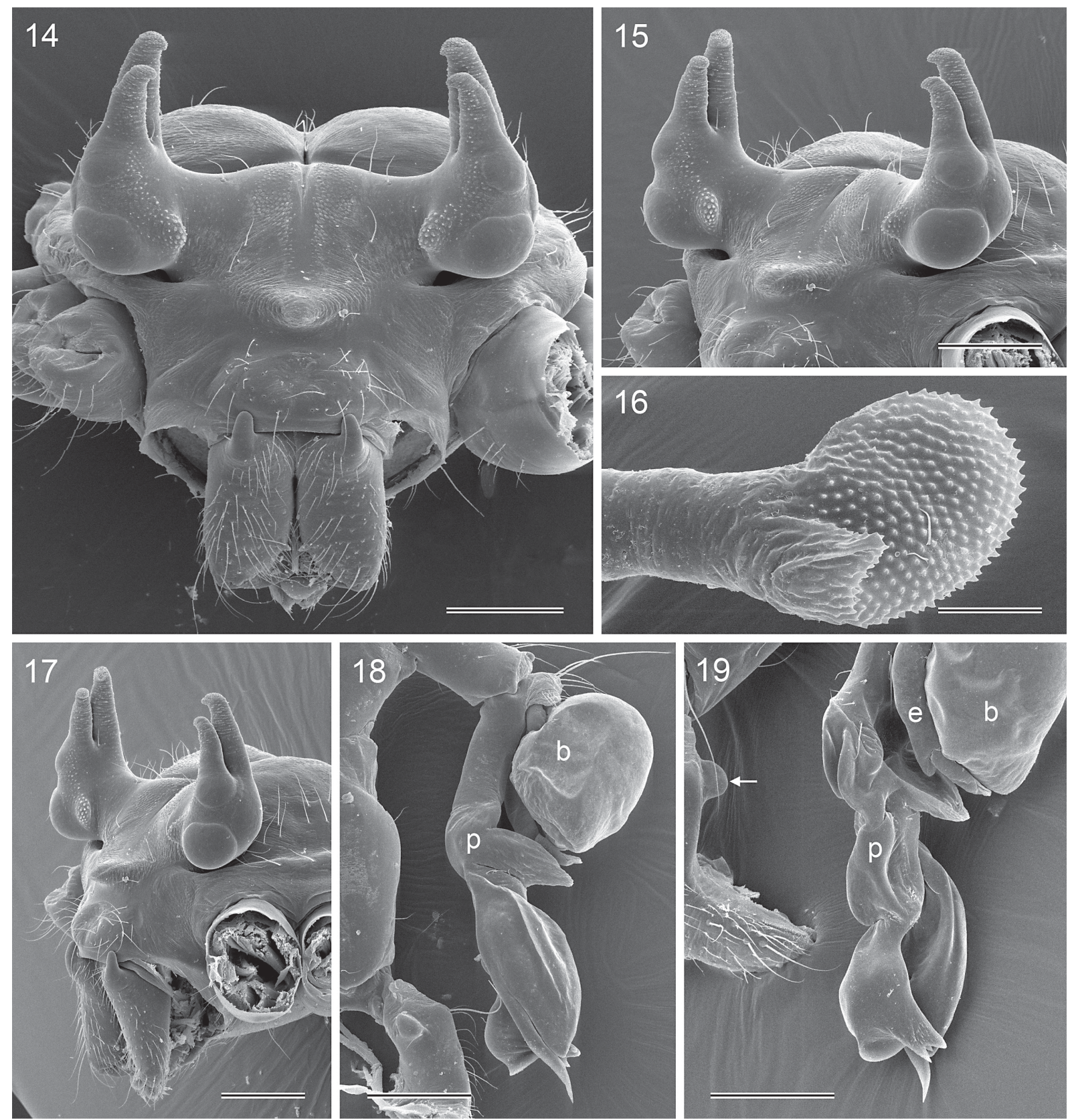

Figs 14-19. Hantu kapit gen. et sp. nov., ZFMK Ar 15069. 14-15. Male prosoma, frontal and slightly oblique frontal views. 16. Tip of right male palpal trochanter apophysis. 17. Male prosoma, oblique frontal view. 18. Left procursus and genital bulb, prolateral view. 19. Right procursus and bulb, retrolateral view (arrow points at ventral process on coxa). Abbreviations: $b=$ genital bulb; $e=$ embolus; $\mathrm{p}=$ procursus. Scale lines: $50 \mu \mathrm{m}$ (16); $200 \mu \mathrm{m}(14-15,17-19)$. 
without processes; patella unusually long; tibia long and slender. Procursus highly complex, apparently with several hinges between distinctive sclerites. Bulb simple, weakly sclerotized embolus with subdistal branch.

LEGS. With single ventral row of $\sim 25$ spines on femora 1 ; without curved hairs; with short vertical hairs in two dorsal rows on all femora and tibiae; retrolateral trichobothrium on tibia 1 at $6 \%$; prolateral
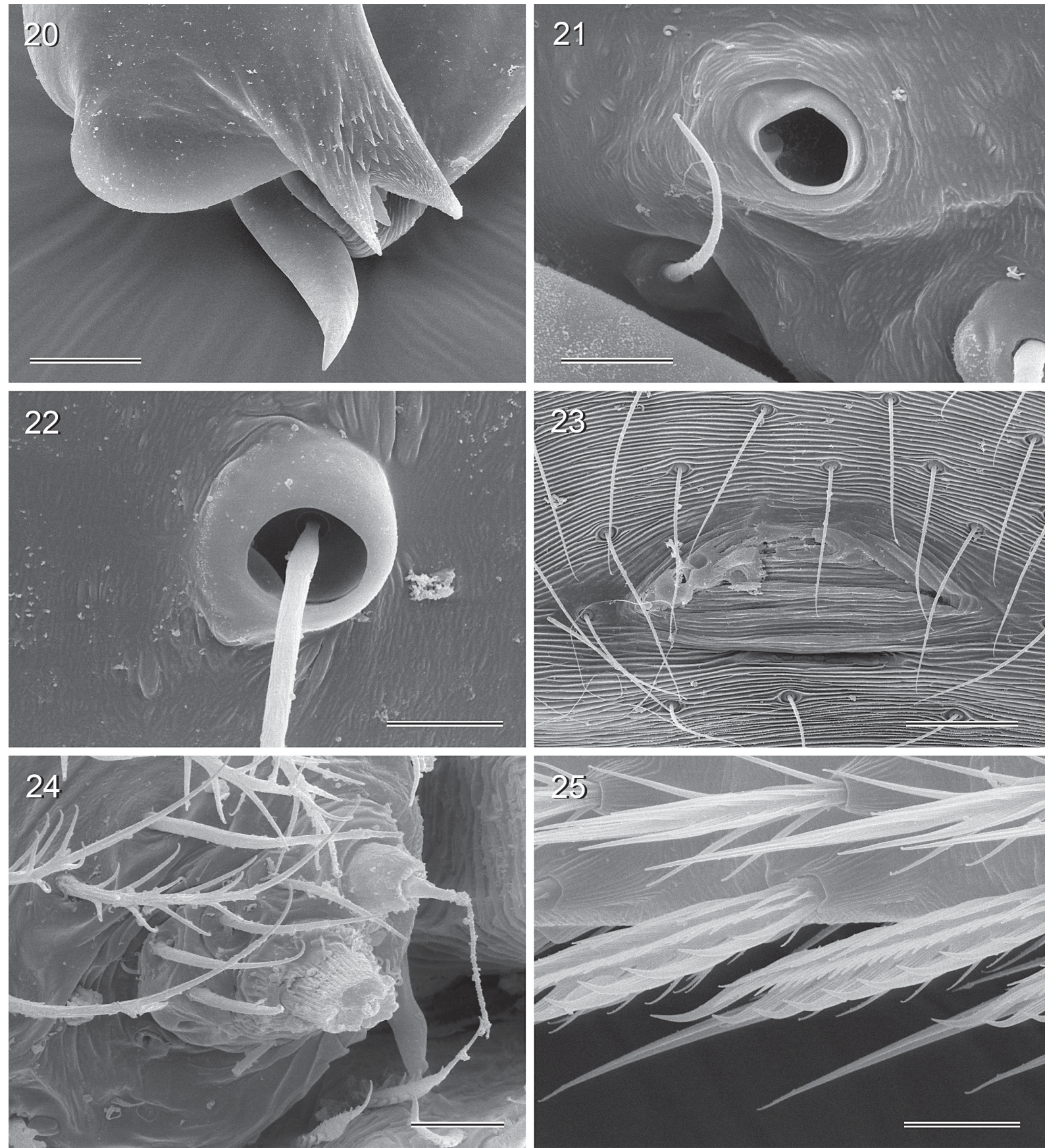

Figs 20-25. Hantu kapit gen. et sp. nov., ZFMK Ar 15069. 20. Tip of right procursus, retrolateral view. 21. Male palpal tarsal organ. 22. Trichobothrium base on male palpal tibia. 23. Male gonopore. 24. Male ALS. 25. Comb-hairs on male tarsus 4. Scale lines: $8 \mu \mathrm{m}(21)$; $10 \mu \mathrm{m}(22,24-25)$; $40 \mu \mathrm{m}(20,23)$. 
HUBER B.A., New spider genus from Sarawak

trichobothrium absent on tibia 1, present on other tibiae. Tarsus 1 pseudosegments indistinct, only distally $\sim 15$ visible in dissecting microscope.

Male (variation)

Tibia 1 in 7 other males: 5.6-5.9 (mean 5.7). Spines on femora variable in thickness and number $(20-30)$.

Female

In general similar to male (Fig. 2); ocular area unmodified, triads closer together (distance PME-PME $220 \mu \mathrm{m}$ ), not on stalks; clypeus unmodified; no spines on femora; fewer vertical hairs on femora and tibiae (but especially on tibiae also with higher than usual density). Tibia 1 in 4 females: 4.7, 4.8, 4.9, 4.9. Epigynum large dark plate, weakly sclerotized, slightly protruding and with many fine transversal folds, especially in posterior half (Figs 13, 40, 41); with distinctive scape, pale whitish distally; internal genitalia as in Figs 12 and 42.

\section{Natural history}

The spiders were found in domed webs in small holes in the ground along a river in well-preserved forest.

\section{Distribution}

Known from type locality near Kapit only (Fig. 7).

Hantu niah gen. et sp. nov. urn:lsid:zoobank.org:act:0C378095-994C-427A-8989-E119A644A7EC

Figs 3-6, 26-39, 43-45

Gen.n. Bor20 - Huber et al. 2015a: 73-74.

\section{Diagnosis}

Easily distinguished from H. kapit gen. et sp. nov. by absence of horns in male ocular area (Fig. 31), by highly distinctive male palp (Figs 26-27; square-shaped trochanter apophysis; dorsal process on procursus), by strong distal apophyses on male chelicerae (Fig. 28), and by scape on epigynum (Figs 29, 43) more sclerotized and without fine transversal folds. From other putatively close relatives in the genera Khorata and Savarna by male procursus shape (dorsal process) and epigynal scape.

\section{Etymology}

The species name is derived from the type locality; noun in apposition.

Type material

MALAYSIA-BORNEO: holotype, ${ }^{\AA}$, Sarawak, Niah Cave N.P., forest near cave, $3.814^{\circ} \mathrm{N}, 113.771^{\circ} \mathrm{E}$, 40 m a.s.l., 28 Jul. 2014 (B.A. Huber), ZFMK (Ar 15071).

\section{Other material examined}

MALAYSIA-BORNEO, Sarawak: $10 \hat{\partial} \widehat{\partial}^{2}, 15$ 우, 1 juv., same data as holotype, ZFMK (Ar 15072-73;

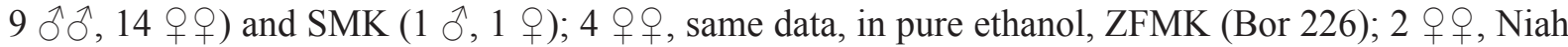
Cave N.P., forest along main trail, 3.814-3.821 ${ }^{\circ} \mathrm{N}, 113.763-113.771^{\circ} \mathrm{E}, 20-40 \mathrm{~m}$ a.s.l., 27 Jul. 2014 (B.A. Huber, S.B. Huber), ZFMK (Ar 15074); 1 , 1 juv., same data, in pure ethanol, ZFMK (Bor 177). 


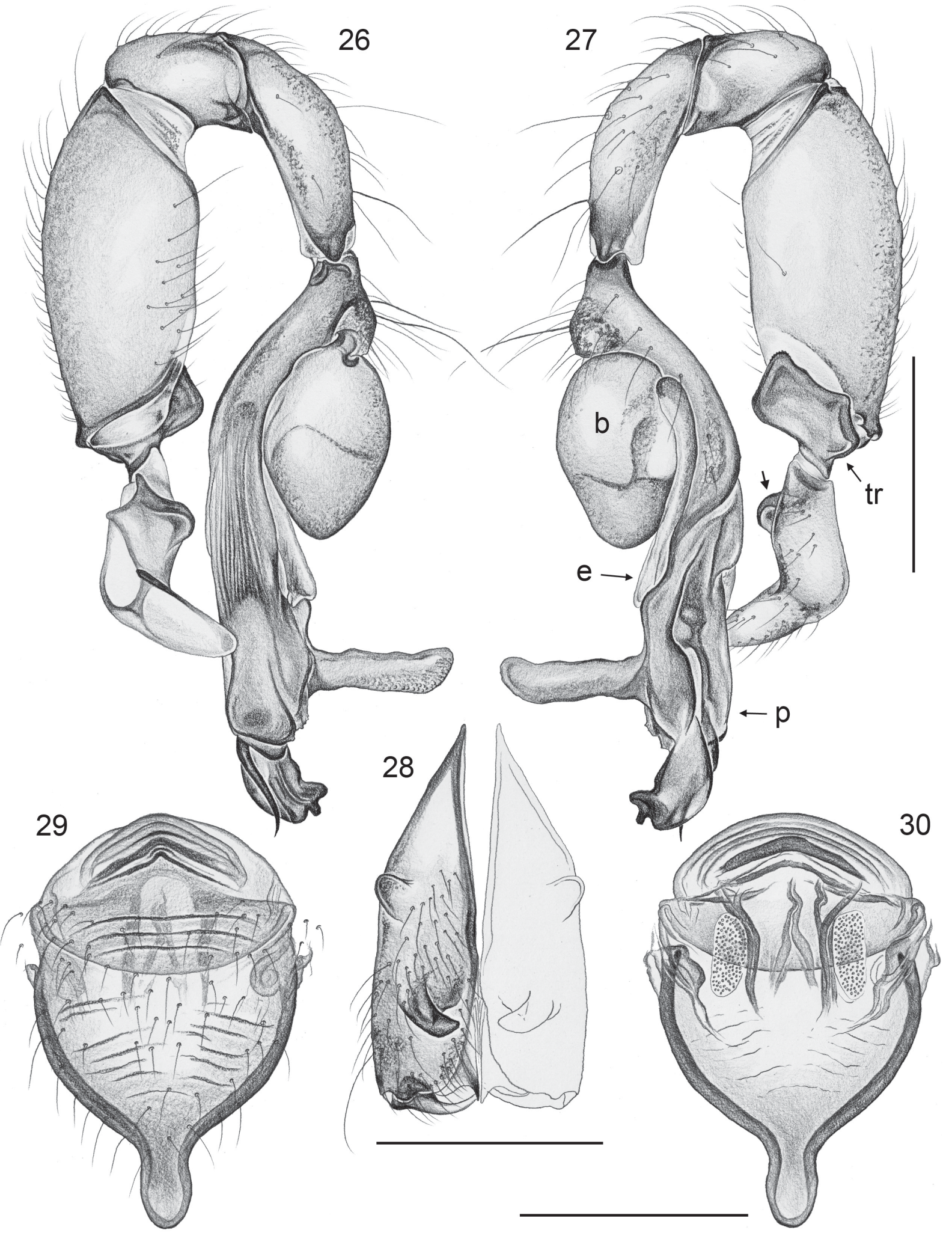

Figs 26-30. Hantu niah gen. et sp. nov., ZFMK Ar 15072-73. 26-27. Left male palp, prolateral and retrolateral views (arrow points at ventral process on coxa). 28. Male chelicerae, frontal view. 2930. Cleared female genitalia, ventral and dorsal views. Abbreviations: $b=$ genital bulb; $\mathrm{e}=$ embolus; $\mathrm{p}=$ procursus; $\operatorname{tr}=$ trochanter. Scale lines: $0.5 \mathrm{~mm}(26-27,29-30) ; 0.3 \mathrm{~mm}(28)$. 
HUBER B.A., New spider genus from Sarawak
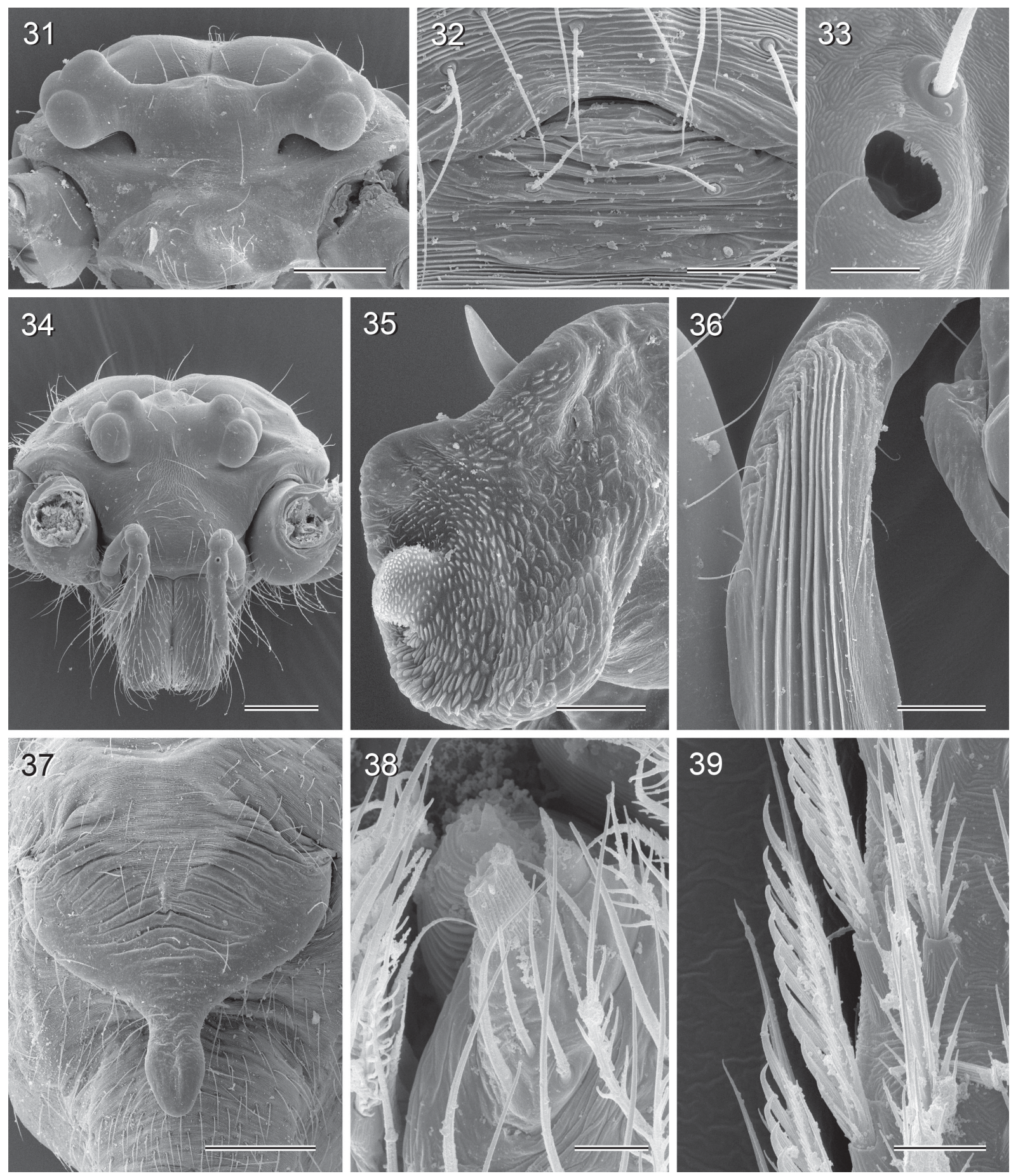

Figs 31-39. Hantu niah gen. et sp. nov., ZFMK Ar 15072-73. 31. Male prosoma, anterior view. 32. Male gonopore. 33. Male palpal tarsal organ. 34. Female prosoma, frontal view. 35. Tip of right procursus, retrolateral view. 36. Lamellae of left procursus, prolateral view. 37. Epigynum, ventral view. 38. Male ALS. 39. Comb-hairs on male tarsus 4. Scale lines: $8 \mu \mathrm{m}(33) ; 10 \mu \mathrm{m}(38-39) ; 30 \mu \mathrm{m}(32,35) ; 80 \mu \mathrm{m}$ (36); $200 \mu \mathrm{m}(31,34,37)$. 


\section{Description}

Male (holotype)

Measurements. Total body length 2.3, carapace width 1.0. Leg 1: $20.5(5.0+0.4+5.1+7.7+2.3)$, tibia 2: 3.0, tibia 3: 2.2, tibia 4: 2.9; tibia $1 \mathrm{~L} / \mathrm{d}: 58$. Distance PME-PME $420 \mu \mathrm{m}$, diameter PME $90 \mu \mathrm{m}$, distance PME-ALE $25 \mu \mathrm{m}$, no AME.

COLOR. Carapace light ochre with narrow lateral dark margins and large median dark mark including ocular area. Clypeus not darkened. Sternum dark brown. Legs ochre to light brown, without dark rings. Abdomen grey with large dorsal and lateral marks; ventrally with three large dark marks (in genital area, at spinnerets, and in-between).

Body. Habitus as in Figs 3-4; ocular area slightly raised, each triad on short stalk directed toward lateral (Fig. 31); carapace with shallow but distinct thoracic furrow; clypeus unmodified; sternum wider than long $(0.65 / 0.55)$, unmodified. Chelicerae as in Fig. 28, with pair of proximal lateral apophyses and pair of strong distal apophyses curved toward median line; without modified hairs.
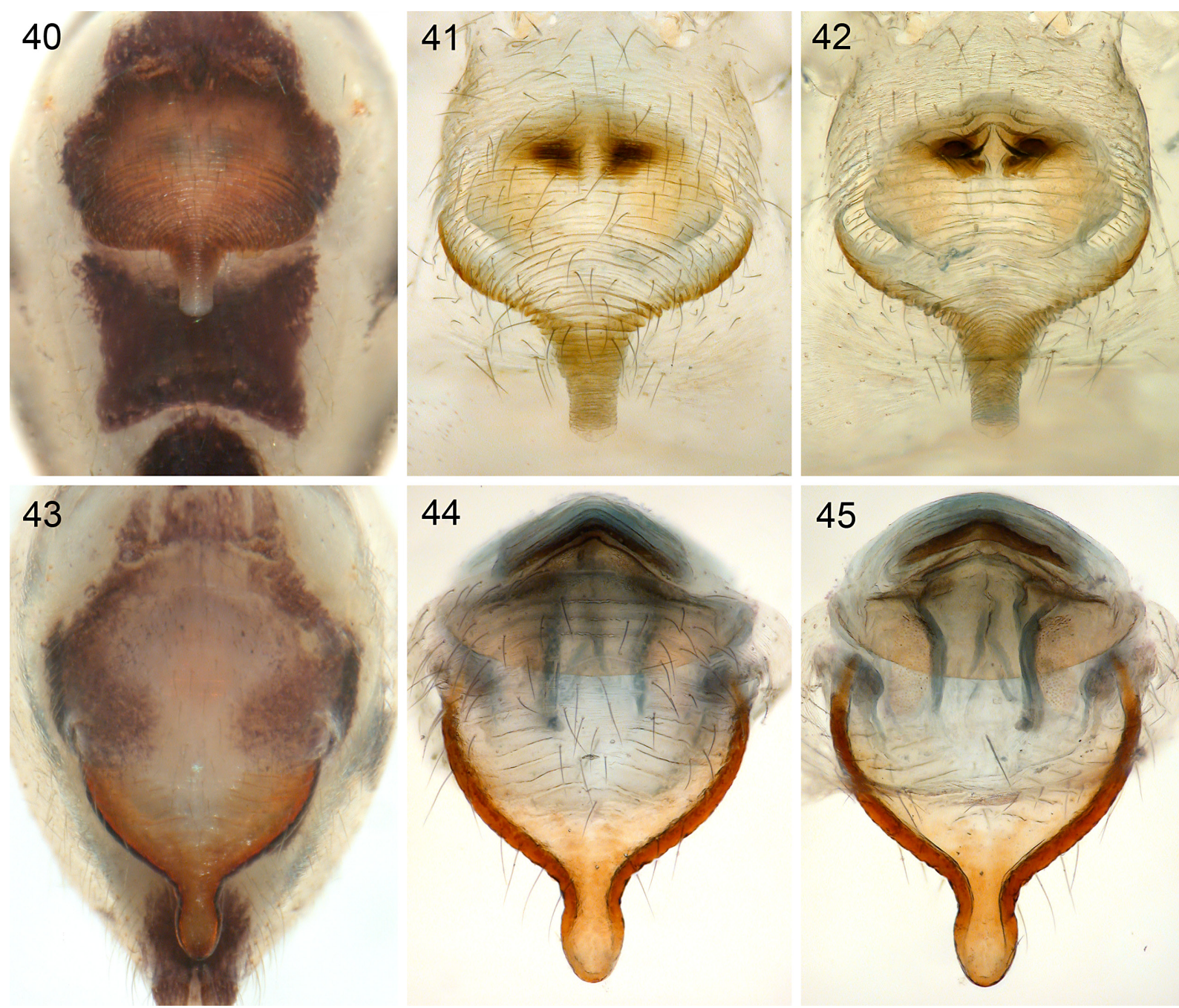

Figs 40-45. Female genitalia; untreated in ventral view, cleared in ventral and dorsal views. 40-42. Hantu kapit gen. et sp. nov., ZFMK Ar 15070. 43-45. Hantu niah gen. et sp. nov., ZFMK Ar 15073. At varying scales. 
PALPS. As in Figs 26-27, coxa with sclerotized protruding rim ventro-distally; trochanter with short but very large, square-shaped ventral apophysis with very small teeth distally; femur very large, without processes; patella unusually long; tibia long and slender. Procursus very long; with distinctive dorsal process and complex tip. Bulb oval, with simple weakly sclerotized embolus.

LeGs. With single ventral row of $\sim 10$ spines on femora 1 ; without curved hairs; with short vertical hairs in two dorsal rows on all femora and tibiae; retrolateral trichobothrium on tibia 1 at $7.5 \%$; prolateral trichobothrium absent on tibia 1, present on other tibiae. Tarsus 1 pseudosegments indistinct, only distally $\sim 20$ visible in dissecting microscope.

Male (variation)

Tibia 1 in 8 other males: 4.8-5.3 (mean 5.0). Margins of carapace sometimes not dark; dorsal pattern on abdomen sometimes indistinct. Number and thickness of spines on femora variable, from few barely thicker hairs (small males) to $\sim 20$ distinct spines (large males).

\section{Female}

In general similar to male (Figs 5-6); eye triads closer together (distance PME-PME $220 \mu \mathrm{m}$ ), not on stalks (Fig. 34); no spines on femora; fewer vertical hairs on femora and tibiae (but especially on tibiae also with higher than usual density). Tibia 1 in 16 females: 4.3-4.7 (mean 4.5). Entire epigynal area protruding, posteriorly sclerotized with distinctive scape (Figs 29, 43, 44); internal genitalia as in Figs 30 and 45 .

\section{Natural history}

The spiders were found close to the ground in small domed webs among and under rocks, under dead leaves, and in little cavities. They were extremely efficient at escaping through the closed hand, then dropped to the ground and remained motionless, becoming essentially invisible.

\section{Distribution}

Known from Niah Cave N.P. only (Fig. 7).

\section{Discussion}

Pholcid spiders are widely known for their long-legged representatives, some of which are synanthropic, but a large number of species in a range of genera are actually relatively short-legged ground and litterdwellers. About half of all currently recognized genera either include or consist entirely of such shortlegged species (e.g., Huber 2005a, 2005b, 2011, 2013, 2015; Huber et al. 2005). This suggests multiple convergent shifts among microhabitats; in fact, molecular data support the notion that such shifts have occurred repeatedly in various directions (Huber et al. 2010; Dimitrov et al. 2013; see also Huber \& Dimitrov 2014).

Ground and litter-dwelling pholcids share a similar habitus to a degree that allows reasonable predictions even for museum specimens without microhabitat information. They are small (body size $\sim 1-3 \mathrm{~mm}$ ), relatively short legged (leg 1 length $<30 \mathrm{~mm}$ ), rather dark (brown), and have a globular or oval abdomen. This combination seems to be extremely rare in pholcids living in other microhabitats. The only apparent exception known to me are West and Central African representatives of the genus Anansus Huber, 2007 that were collected by canopy fogging (Huber 2007).

In Southeast Asia, at least seven pholcid genera other than Hantu gen. nov. include ground and litterdwelling representatives: Aetana Huber, 2005; Belisana Thorell, 1898; Holocneminus Berland, 1942; Pholcus Walckenaer, 1805; Savarna Huber, 2005; Spermophora Hentz, 1841; and Wugigarra Huber, 2001. 


\section{Acknowledgements}

I thank Charles Leh Moi Ung and the Sarawak Museum Department for assistance in the request of permits and in field logistics, and Samuel B. Huber for help in the field. The Natural History Museum in Kuching kindly offered its facilities as the base of the field work. Permits were received from the Forest Department, Sarawak (Permit No. NCCD.907.4.4(JLD.10)-211, Park Permit No. 174/2014). I thank Facundo M. Labarque and an anonymous reviewer for valuable comments on the manuscript. The German Research Foundation provided financial support (DFG Project HU 980/11-1).

\section{References}

Brown B.V. 1993. A further chemical alternative to critical-point-drying for preparing small (or large) flies. Fly Times 11: 10.

Dimitrov D., Astrin J.J. \& Huber B.A. 2013. Pholcid spider molecular systematics revisited, with new insights into the biogeography and the evolution of the group. Cladistics 29: 132-146. http://dx.doi. org/10.1111/j.1096-0031.2012.00419.x

Huber B.A. 2005a. High species diversity, male-female coevolution, and metaphyly in Southeast Asian pholcid spiders: the case of Belisana Thorell 1898 (Araneae, Pholcidae). Zoologica 155: 1-126.

Huber B.A. 2005b. Revision of the genus Spermophora Hentz in Southeast Asia and on the Pacific Islands, with descriptions of three new genera (Araneae: Pholcidae). Zoologische Mededelingen 79-2 (4): 61-172.

Huber B.A. 2007. Two new genera of small, six-eyed pholcid spiders from West Africa, and first record of Spermophorides for mainland Africa (Araneae: Pholcidae). Zootaxa 1635: 23-43.

Huber B.A. 2011. Revision and cladistic analysis of Pholcus and closely related taxa (Araneae, Pholcidae). Bonner zoologische Monographien 58: 1-509.

Huber B.A. 2013. Revision and cladistic analysis of the Guineo-Congolian spider genus Smeringopina Kraus (Araneae, Pholcidae). Zootaxa 3713: 1-160. http://dx.doi.org/10.11646/zootaxa.3713.1.1

Huber B.A. 2015. Small scale endemism in Brazil's Atlantic Forest: 14 new species of Mesabolivar (Araneae, Pholcidae), each known from a single locality. Zootaxa 3942: 1-60. http://dx.doi.org/10.11646/ zootaxa.3942.1.1

Huber B.A. \& Dimitrov D. 2014. Slow genital and genetic but rapid non-genital and ecological differentiation in a pair of spider species (Araneae, Pholcidae). Zoologischer Anzeiger 253: 394-403. http://dx.doi.org/10.1016/j.jcz.2014.04.001

Huber B.A., Fischer N. \& Astrin J.J. 2010. High level of endemism in Haiti’s last remaining forests: a revision of Modisimus (Araneae: Pholcidae) on Hispaniola, using morphology and molecules. Zoological Journal of the Linnean Society 158: 244-299. http://dx.doi.org/10.1111/j.1096-3642.2009.00559.x

Huber B.A. \& Fleckenstein N. 2008. Comb-hairs on the fourth tarsi in pholcid spiders (Araneae, Pholcidae). Journal of Arachnology 36: 232-240. http://dx.doi.org/10.1636/CSh07-71.1

Huber B.A., Nuñeza O.M. \& Leh Moi Ung C. 2015a. Revision, phylogeny, and microhabitat shifts in the Southeast Asian spider genus Aetana (Araneae, Pholcidae). European Journal of Taxonomy 162: 1-78. http://dx.doi.org/10.5852/ejt.2015.162

Huber B.A., Petcharad B. \& Bumrungsri S. 2015b. Revision of the enigmatic Southeast Asian spider genus Savarna (Araneae, Pholcidae). European Journal of Taxonomy 160: 1-23. http://dx.doi. org/10.5852/ejt.2015.160 
HUBER B.A., New spider genus from Sarawak

Huber B.A., Rheims C.A. \& Brescovit A.D. 2005. Two new species of litter-dwelling Metagonia spiders (Araneae, Pholcidae) document both rapid and slow genital evolution. Acta Zoologica 86: 33-40. http:// dx.doi.org/10.1111/j.0001-7272.2005.00184.x

Manuscript received: 12 October 2015

Manuscript accepted: 10 December 2015

Published on: 1 April 2016

Topic editor: Rudy Jocqué

Desk editor: Kristiaan Hoedemakers

Printed versions of all papers are also deposited in the libraries of the institutes that are members of the EJT consortium: Muséum national d'Histoire naturelle, Paris, France; Botanic Garden Meise, Belgium; Royal Museum for Central Africa, Tervuren, Belgium; Natural History Museum, London, United Kingdom; Royal Belgian Institute of Natural Sciences, Brussels, Belgium; Natural History Museum of Denmark, Copenhagen, Denmark. 